\title{
DAULAT RA'JAT AND THE IDEAS OF THE PENDIDIKAN NASIONAL INDONESIA
}

\author{
J. D. Legge
}

In 1948 Sjahrir and a group of his associates broke away from the Partai Sosialis led by Amir Sjarifuddin to form the Indonesian Socialist Party (PSI). It was a move which followed naturally from the differences in temper and outlook that had been present in the original party. Thereafter the PSI became an important element in the early political alignments of the Republic of Indonesia and, even after its electoral failure in 1955 and the banning of the party by Sukarno in 1960, the PSI stream remained as a distinct grouping within Indonesia and continued to represent a particular way of viewing the problems of the Republic The party was dominated, said Feith, by intellectuals whose thinking was "closely related to the Western democratic socialist tradition." Its emphasis was on modernization and the rational planning of economic development, and its ideas influenced many outside its own ranks. ${ }^{1}$ Nevertheless, the group is not easy to identify with precision, nor is it clear that it should be seen as a single group.

The present article is the first part of an attempt to identify this stream and to consider alternative interpretations which observers have given of it. Western students of the Indonesian revolution and the early years of independence established a warm rapport with members of the PSI, and it was from Sjahrir and his followers that they tended to draw their perceptions of the internal struggles within the republic during the revolution and after. Later observers, working in a period when the PSI had lost its former influence, have questioned those perceptions and, faced with the plain fact of the party's eclipse, they have perhaps underestimated the role of its members even during the late forties and early fifties. If so, it is time to reexamine the character and contribution of the group which grew up about Sjahrir in the mid-forties and became the core of the PSI.

In attempting such a reassessment it is necessary to go back at least as far as the early thirties, when a fundamental division opened up within Indonesia's secular nationalist movement.

In the late twenties, largely as a result of the efforts of Sukarno, the movement appeared to have gained a significant degree of unity. It was, perhaps, a precarious unity, resulting partly from the destruction of the PKI after the revolts of 1926 and 1927, and partly from the loss of momentum of Sarekat Islam, which had been the major nationalist organization almost from its foundation in 1912 until its rivalry with the PKI in the early twenties. The decline of Sarekat Islam and the suppression of the PKI had left the field free for the Indonesian Nationalist Party (PNI), formed in 1927 as the result of a combination of initiatives stemming largely from Perhimpunan Indonesia, the association of Indonesian students studying in the Netherlands, and from the Study Club movement that had developed within the

1. Herbert Feith, The Decline of Constitutional Democracy in Indonesia (Ithaca: Cornell University Press, 1962), pp. 129-30. 
Indies during the twenties. From 1927 the new party established its credentials as the main nationalist organization. Sukarno, as chairman of the party, had stressed the overwhelming importance of nationalist unity. He had been able to hold in balance, for a time, the quite diverse elements which existed within the party and he had also secured the cooperation of other broadly nationalist organizations outside it. In 1927 he managed to draw some of these into the loosely linked Association of Political Organizations of the Indonesian People (PPPKI). The establishment of the PNI, the euphoric atmosphere of its congresses in 1928 and 1929, its participation in the Youth Congress of October 1928 at which, together with other organizations, it subscribed to the famous Youth Pledge, seemed to confirm its position as the leader of a nationalism based on a perception of "one land, one people, and one language."

This progress was interrupted by the arrest, in December 1929, of Sukarno and three of his colleagues, and their subsequent trial and imprisonment. Under the more cautious leadership of Sartono the PNI decided to dissolve itself and to form, as its successor, an ostensibly new organization--the Indonesia Party (Partindo). This move was not universally accepted by the PNI's membership and supporters. In many places those who disagreed with Sartono's action set up rival organizations, calling themselves Independent Groups (Golongan Merdeka) or sometimes Study Clubs. ${ }^{2}$ With the return of Sjahrir from the Netherlands at the end of 1931, and of Hatta in August 1932, and with the merging of the Independent Groups in December 1931 to form the Pendidikan Nasional Indonesia--or the New PNI (PNI Baru) - the ingredients were present for a divided movement and a divided leadership. Sukarno, on his release from Sukamiskin prison on the last day of December 1931, was faced by the existence of the two groups--Partindo and the New PNI-and his first efforts were directed to closing the gap and reuniting the movement. He failed, and decided to throw in his own lot with Partindo. Thereafter the division between the two streams remained. It was still visible when the exiles returned from Boven Digul and Banda Naira and from Bengkulu in 1942, and it continued after the attainment of independence. There were to be shifts and realignments from time to time, both before and after the proclamation of independence. Some individual members of the New PNI were later to leave their former allies and move to the right or the left. But the broad division of 1932 nevertheless remained recog nizably visible in Indonesia's subsequent political history.

When the Pendidikan Nasional Indonesia was formed, Sjahrir's first cabinet was fourteen years in the future and the formation of the PSI was sixteen years away. But to the participants of the forties the continuities seemed obvious. In 1948 Sjahrir regarded the newly formed PSI as the heir to the Pendidikan. ${ }^{3}$ Its ideas and its strategy, in his view, derived from the earlier party, and it is with the formation of the New PNI that the search for the soul of the later PSI must start.

A number of factors have been advanced to explain the depth of the gulf separating Partindo and the Pendidikan Nasional Indonesia in 1932 and 1933. Differences of temper and personality were certainly important. At a superficial level

2. John E. Ingleson, Road to Exile: The Indonesian Nationalist Movement 19271934 (Singapore: Heinemann, 1979), pp. 144-45, gives a clear account of the organizational complexity of this period.

3. Interview of Sjahrir with George McT. Kahin, February 15, 1949. I am indebted to Professor Kahin for making available to me his notes of his interview with Sjahrir. 
Sukarno, the charistmatic leader, the "lion of the podium" who was able to sway the masses by the sweep of his nationalist vision, stood in sharp contrast to the more reserved, cautious, and analytical Hatta and the sparkling and highly intellectual figure of Sjahrir. Hatta was, of course, the central figure of the New PNI and Sjahrir the junior partner. Born in Bukittinggi in 1902, Hatta had had an early training in political action while still a secondary school student--as secretary of the Padang branch of the Jong Sumatranen Bond and as its treasurer in Jakarta. He went in the early 1920 s to study in Rotterdam where he became the leading figure in the Perhimpunan Indonesia. Under his influence the PI was laying plans for a new nationalist party in the Indies when the initiative was preempted by the formation of the PNI. Hatta's arrest in 1927 and his subsequent trial received great publicity in Indonesia, and his defense speech, published as Indonesia Vrii (Indonesia Free), made him a very visible nationalist leader. Sjahrir was seven years younger than his mentor. Born in 1909, also a Minangkabau, he had gone to study at the University of Amsterdam at the age of twenty. Two years later, his studies unfinished, he returned to Indonesia, essentially as Hatta's representative, to play his part in the political maneuvers which followed Partindo's formation, pending Hatta's own return some months later. In the light of their close partnership it is appropriate to see Hatta and Sjahrir as a pair, and as standing in contrast to Sukarno as representative of a different leadership style.

In fact the contrast was more subtle and complex than that. Sukarno, with his successful chairmanship of the PNI between 1927 and 1929, may have appeared supremely confident of his ability to provide inspirational leadership, but the outward confidence perhaps masked an inner vulnerability. He was made uncomfortable by those who were critical of his expressive political style and, though he believed instinctively that he rather than they had the essence of the matter within him, he remained wary of these intellectually sophisticated leaders who during their period of study in the Netherlands had headed the Perhimpunan Indonesia there. The two sides could not easily work together.

The differences appeared to extend to matters of fundamental political philosophy. Bernhard Dahm attempted to catch the nature of the contrast by describing Partindo as an "Indonesian" party and the New PNI--the party of Hatta and Sjahrir--as a "European" party. John Ingleson rejects that distinction, pointing out that, while Hatta and Sjahrir were Netherlands-educated, so were Sartono, Ali Sastroamidjojo, and other leaders of the old PNI and Partindo; and in fact the Partindo executive was more heavily weighted on the side of Netherlands-trained people than was that of its rival. ${ }^{4}$ But Hatta had stayed longer in Europe than had most other Indonesian students and, unlike those others, he and Sjahrir had become very much a part of Dutch left intellectual circles during their years in Rotterdam and Amsterdam. While opposing Dutch imperialism, and the caste society it had established in the Indies, they were not anti-Dutch as such, and the "European" versus "Indonesian" labels perhaps do hint at real differences in political mentality .

Certainly it has been part of the received view that both the New PNI's leadership and its rank and file had a more sophisticated perception of the nature of imperialism, of the colonial predicament, and of the domestic social order than was represented in the looser and more eclectic approach of the old PNI and Partindo. From the party's more rigorous and systematic theorizing, it is said, there followed the differences of view about political strategy and tactics which were supposed to

4. Bernhard Dahm, Soekarno and the Struggle for Indonesian Independence, trans. Mary F. Somers Heidhues (Ithaca: Cornell University Press, 1969), ch. 4. Ingleson, Road to Exile, pp. 193-94. 
mark the New PNI off from its rival. In particular, it is held that, from the beginning, there was a recognition of the vulnerability of Sukarno's mass party approach and of the need to proceed more cautiously in preparing for a prolonged struggle, to train leaders rather than to seek members, so that the movement would not be dependent upon a small leadership at the top. The Dutch could easily immobilize a mass party by a few swift arrests. What was needed was a smaller, but coherent, well-organized and politically conscious membership which could survive the arrests of its leaders--a party to train cadres rather than to develop a mass membership.

It is this picture which the present article seeks to explore. What were the political ideas of the New PNI? Were they really as distinctive as the members of the party believed them to be? How new and well-defined was the strategy of the party? Such an exploration will provide the setting for further questions. How far did the influence of Hatta and the New PNI survive the particular issues of the early thirties? Were the ideas of the party indeed the same ideas which, over ten years later, bound together a circle of people surrounding Sjahrir and led to the formation of the PSI in 1948 ?

What has become the received view of the New PNI was given persuasive expression by George McT. Kahin in 1952. He described the approach of Hatta and Sjahrir as aiming at the education of the Indonesian nationalist movement to political maturity and a thorough understanding of nationalist principles. More specifically, the task of the New PNI--the Pendidikan Nasional Indonesia--was to build up cadres of first- and second-echelon leaders who could, in turn, educate others. "Small cadres of self-reliant, strongly conscious nationalists would in the long run, they were convinced, achieve the independence that mass support of short-careered, charismatic leaders could not." 5

That judgment has been accepted by later students (including the present writer ${ }^{6}$ ). John Ingleson noted that the difference between the New PNI and the old was not simply a difference between the latter's advocacy of mass action and the former's advocacy of cadre forming. In his view the difference was that the New PNI believed that mass action should wait until the movement was strong and disciplined, with a correctly educated, politically aware, mass membership. He added, however, that this was only possible if recruitment was indeed carried out "step by step with the development of a solid leadership core of party cadres". 7 He also pointed to Hatta's view, as early as 1929, or even 1927 , that a nationalist party should devote its energies to establishing "a small, politically conscious and disciplined core membership" before seeking a mass membership.

5. George McT. Kahin, Nationalism and Revolution in Indonesia (Ithaca: Cornell University Press, 1952), p. 93.

6. See the account of the division between Sukarno and Hatta in J. D. Legge, Sukarno: A Political Biography (New York: Praeger, 1972), ch. 5, especially pp. 121 and 127-28.

7. Ingleson, Road to Exile, p. 169. This characterization of the differences between the two parties forms the main thesis of Ingleson's study. See ibid., p. 32 .

8. J. E. Ingleson, Perhimpunan Indonesia and the Indonesian Nationalist Movement, 1923-1928, Monash Papers on Southeast Asia, no. 4 (Clayton, Vic.: Monash University Centre of Southeast Asian Studies, 1975), p. 66. 
This is also certainly the judgment that the leaders of the New PNI stream came to make about themselves later on. In his autobiography, Hatta recalled a meeting of himself, Sukarno, and Sartono towards the end of September 1932, at which the three men discussed whether there was any possibility of uniting Partindo and the Pendidikan Nasional Indonesia. Hatta insisted that it was better for the two parties to keep their separate identities but, where appropriate, cooperate with each other. After this discussion he met with leaders of the New PNI who, so he recalls, reaffirmed that their prime task was to prepare trained cadres able to guide others and instruct them in the methods of analyzing the contemporary situation. Those members of the party who were skilled agitators--Burhanuddin, Maskun, and others --were persuaded to accept the cadre approach as the right way to proceed. ${ }^{9}$

As he described it in 1949, Sjahrir had had the same perception of the PNI Baru's original objectives. The task of the Pendidikan, he said then, had been to train a body of people who were responsible and politically conscious: "In Indonesia, cadres were more important than mass support." 10 He was concerned that the PSI should follow the same approach, aiming not at a numerically large membership but at a party of convinced socialists. ${ }^{11}$

Perhaps. But there is at least a possibility that this image of the New PNI was a projection back to 1931 and 1932 of strategic formulations which crystallized later. Was the image of mass leaders being criticized by the advocates of a longer, more hard-headed, preparation for nationalist strength through the education of a more broadly based leadership--of a mass party approach being challenged by a cadre party approach--the correct image? Or was it a view that Hatta, Sjahrir, and others developed after the event? Was that the way that they saw themselves in the mid-1940s and after?

In Hatta's case, the idea of training many Sukarnos rather than simply applauding the one was certainly expressed as early as 1929, and he had been critical of the PPPKI on the grounds that its unity was superficial. The New PNI intended to provide a party unity on the basis of a doctrine understood and shared by all its members. He may very well have developed, by 1932 , a clearly worked out perception of the party he wanted to build; and Sjahrir may well have shared that perception. There are some grounds, however, for doubting whether the Pendidikan Nasional Indonesia as a whole had, from its inception, set its sights so clearly in that direction, or even whether cadre training was so clear a strategy to its leaders as it later became. The building of a new party, and the shaping of its principles and its methods, are likely to have been a matter of compromise and argument and gradual adaptation to the demands of a changing situation, rather than simply of applying an already completed blueprint. The leaders of the New PNI were but recently returned from the Netherlands where they had been able to observe the workings of Dutch political organizations. They had viewed the Indonesian nation. alist movement from a distance and it was from the safety of that distance that they had formulated their criticisms of the Indonesian leadership and their prescriptions of how the nationalist movement should proceed in future. They now had to adjust to the realities of the situation that confronted them in Indonesia itself, and to do business with people who appeared to be broadly in tune with their thinking but whose actual experience of day to day political action had given them a different perspective and their own authority. It is likely that, in these circumstances, the conception of the new party as committed to preparing for revolutionary change

9. Mohammed Hatta, Memoir (Jakarta: Tintamas, 1979), p. 263.

10. Interview of Sjahrir with George McT . Kahin, February 15, 1949.

11. Interview of Sjahrir with George McT. Kahin, November 21, 1948. 
through the education of a sophisticated and politically conscious leadership, would take some time to evolve, though it would not be surprising if, later on, the New PNI's leaders were to project their matured views about tactics back to the party's very formation and to see themselves as following principles of organization which were already fully developed. As Ingleson has pointed out, ${ }^{12}$ the PNI Baru cannot simply be identified with Hatta and Sjahrir. It was very much their creation, but the views of others had their place also in defining the party's character.

The obvious place to look for the interplay of the views of the Pendidikan Nasional Indonesia is in the pages of its own paper, Daulat Ra'jat. Daulat Ra'jat was founded in September 1931 as the organ of the Golongan Merdeka (Independent Groups) formed by the amalgamation of a number of smaller organizations of former PNI members who were critical of the line taken by Sartono, as leader of the old PNI, after Sukarno's arrest, and critical, in particular, of the decision to form Partindo as a new legal entity to replace the old PNI. In December, as we have seen, the Golongan Merdeka and other groups merged to form the Pendidikan Nasional Indonesia, and Daulat Ra'jat then became the organ of the new party. Sjahrir returned from the Netherlands in late 1931 to take over the chairmanship of the party and Daulat $R a^{\prime}$ jat announced, in issue No. 12, January 10, 1932 , that its editorship would be under his direction. Hatta returned later--in September 1932-and became chairman of the editorial board. Between them, Hatta and Sjahrir provided the intellectual backbone to the dissident stream of secular nationalism, and one would expect to find in the pages of their journal a coherent statement of their strategical and tactical views and of their differences with the line of the old PNI and the new Partindo.

In fact, for the greater part of its short life, Daulat Ra'jat proved to be much less distinctive than one might have expected. Secular it certainly was. Radical it certainly was. And it was nationalist--nationalist in a way that Sarekat Islam was not and that the old PNI was. It was concerned to explore the character of colonial subjection, and it had a clear perception of national independence from Dutch rule as the primary goal of nationalist struggle. Thus far it marched with Persatuan Indonesia, the journal of the old PNI. It can also be described as "Western" in style and approach: that is to say it was rational and analytical in its approach to political problems, and its conceptions of political organization and action and of political and social theory drew directly on the main currents of radical European thought. ${ }^{13}$ It was socialist in outlook and was not anxious to forge alliances with elements that did not share that view. One of its central concerns was with the nature of imperialism. Dutch rule was seen as part of a wider phenomenon. Merely to struggle against the Dutch was not enough; only by understanding the character of imperialism in general could a party successfully organize against this particular expression of it. But again, much of its writing on these questions was completely in tune with that of Persatuan Indonesia under Sukarno's editorship and with Sukarno's own writings between 1927 and $1933 .{ }^{14}$

12. Ingleson, Road to Exile, p. 193.

13. Its Western flavor was important, but perhaps a little surprising in that, in spite of the presence in its leadership of such Netherlands university products as Hatta and Sjahrir, the New PNI seems to have reached down to lower social levels than were normally reached by Partindo. (See Ingleson's analysis of this difference in social composition. Road to Exile, pp. 193-94.)

14. The present article does not attempt a detailed comparison of the content and 
There were, admittedly, some important differences of emphasis between its approach and that of the old PNI that are worth exploring. The question of nationalist unity was one such matter on which the New PNI took sharp issue with the old. Under Sukarno's leadership the old PNI had sought to unify the nationalist movement, believing that independence was a goal on which all could unite. Questions of social structure--divisive questions--could be left until after independence had been achieved. Any allies in the struggle for independence were worth having, and even quite fundamental differences on other matters could be played down for the time being in the interests of the independence struggle. Sukarno's patient construction of that loose confederation--the PPPKI--represented the application of that view, and in the eyes of the New PNI it represented a fundamentally misconceived approach. For Sukarno, the creation of nationalist unity out of diverse elements was the major concern. Against that approach Hatta believed that the search for unity at all costs made for weakness, not strength. The PPPKI, argued Hatta, was not a real unity. It was not a persatuan (unity) but a persatéan--a collection of bits and pieces (a pun derived from saté--small pieces of meat grilled on a skewer). ${ }^{15}$ The pages of Daulat Ra'jat returned continually to the theme that a unity not based on the acceptance of common principles and a common strategy was not worth having. Here was the expression of the New PNI's theoretical self-consciousness. Revolutionary action, to be successful in the long run, needed to be based on a correct analysis of social reality and the trends of history.

The point was developed in a series of articles by Sjahrir in successive numbers of the journal in January and February 1932. ${ }^{16}$ The word "unity," he argued in the first article, was often used without close definition. It was necessary to know "what is to be united, for what, and with what intention." Questions at issue between different parties might relate to differences of strategy or merely to differences of tactics, the latter being less important than the former. And it was basic strategy that was in question in the rivalry between the New PNI and Partindo. This was the kind of difference that was not easily resolved. A narrow unity based on a correct reading of a political situation was better than a vague common sentiment. Sentiment, said Sjahrir in his concluding article, was important to support struggle, but for struggle to be effective it was necessary to know what had

style of Daulat Ra'jat with the writings of leaders or members of the old PNI. Evidence of the old PNI's approach, with which that of the new is compared, can be found in Persatuan Indonesia and the published writings of Sukarno. See, e.g., Sukarno's defense speech, Indonesia Menggugat [Indonesia Accuses] (Jakarta: Departemen Penerangan, 1961) and the articles collected in Dibawah Bendera Revolusi [Under the Banner of Revolution], I (Jakarta: Panitya Penerbit Dibawa dera Revolusi, 1964), including "Mentjapai Indonesia Merdeka" [Achieving Independent Indonesia] (pp. 285-89).

15. Hatta, "Persatoean ditjari, Per-sate-an jang ada" [Unity sought, Saté-like unity achieved], Daulat $R a^{\prime}$ jat [hereafter $D R$ ], No. 22, April 20, 1932.

16. Sjahrir, "Faham Persatoean Didalam Strategie dan Taktik Perdjoeangan" [The understanding of unity in the strategy and tactics of struggle], $D R$, Nos. 14, 15, and 16 of January 30 , February 10, and February 20, 1932, respectively. Only the third article was signed by Sjahrir, but they form a continuous argument and are obviously part of the same essay. The series was followed by a fourth article (unsigned, but probably by Sjahrir), "Barisan Persatoean Baroe" [A New United Front], $D R$, No. 17, February 29, 1932, which explored the possibilities of genuine common action. It envisaged an elaborate hierarchy of councils representing, at each level, the constituent parties in the united front and extending from the center through provinces to the village level and with popular control at each level. 
to be done; it was necessary to understand the situation and to be able to calculate its possibilities. In supporting the PPPKI, Partindo was attempting to bring together parties very different in character from each other. The PPPKI was thus not really a union but a conglomeration of separately existing organizations, without any acceptance of common principles to bind them together. The constituent parties retained their freedom and any action required the consent of all. In consequence, the conservative elements in the grouping acted as a brake on the radical elements. Only when Marhaen had learned the nature of the struggle and become his own master and when the leadership was genuinely responsive to his wishes, would the movement progress.

A real unity, then, must be based on political consciousness and on an understanding of the present situation, and it must be close enough to enable the struggle to be conducted by one united body.

This was a recurring theme in the pages of Daulat Ra'jat. Sjahrir's criticism of the PPPKI was exactly in tune with that of Hatta, and Hatta returned frequently to statements of the same view. In a comment on Sukarno's decision to join Partindo, he argued that the experience of the old PNI had lessons for the new. Unity could not be achieved where real differences of principle existed; the understanding of the people and the understanding of the bourgeoisie and the aristocracy could not be united. In the new circumstances, the unity of all groups would mean destroying the principles of each. ${ }^{17}$ He continued the theme in later articles, repeating his persatéan joke ${ }^{18}$ and insisting that the revolutionary-ness of different groups might depend merely on the stage of the struggle. Other writers followed the same line. Different elements might combine at an early stage of struggle, said an anonymous contributor, but, once freedom had been attained, former friends would become present enemies according to their class needs. ${ }^{19}$ In similar vein an article by Maskun argued that unity in political parties could not just be a unity of men. It had to be a unity of principles and strategies. He condemned gado-gado unity as Hatta had condemned persatéan. ${ }^{20}$ As the PPPKI showed, radicalism could not just join with moderation: if real unity could not be achieved it would be better for each stream to be separate.

In this way the New PNI justified its preservation of a separate identity and indicated the sort of terms on which united action with other parties might be achieved.

But when it comes to the question: what were the principles on which the real unity was to be based and what were the strategies about which agreement was necessary, the apparent distinction between the old and the New PNI is difficult to keep in focus. In an interesting passage in his January and February 1932 articles on the understanding of unity, Sjahrir stressed the need for precision in theoretical language and thought: Clarity of analysis required clarity of expression. Theoretical thinking must be exact. If we are not able to determine our political calculation, it is because we do not know what we are calculating. "In all political calculation, thinking must be concrete, must be based on the real situation, must

17. Quoted in "Makloemat Sdr Soekarno" [The Declaration of Comrade Soekarno] in $D R$, No. 34, August 20, 1932 .

18. Hatta, "Pendirian Kita" [Our Position], DR, No. 36, September 10, 1932.

19. A, "Revolusioner" [Revolutionary], $D R$, No. 45, December 10, 1932.

20. Maskun, "Arah Kemoeka" [The Way Ahead], DR, No. 73, September 20, 1933. Gado-gado is an Indonesian dish of mixed vegetables. See also the article by Hatta in $D R$, No. 80, November $30,1933$. 
be definite and limited." In much political discourse, by contrast, he noted, terms are not clear and every man can give them his own meaning. ${ }^{21}$ In defining its own position as against that of the old PNI, however, Daulat Ra'jat did not always display this desired precision.

Imperialism must be understood if it is to be combated, said Daulat Ra'jat. The old PNI took the same view. And the New PNI's analysis of imperialism was, like that of the old PNI, essentially a Marxist analysis. Articles on imperialism took broadly the view expressed, for example, in Sukarno's defense speech. European imperialism was seen as economically determined, as being a systematic function of a certain stage of capitalism--the product, in brief, of capitalism in crisis. ${ }^{22}$ In April 1932 Daulat Ra'jat contrasted "political" interpretations of imperialism advanced by bourgeois intellectuals who served merely as an extension of state power, with more fundamental economic interpretations. The former saw imperialism in Indonesia as merely an extension of the power of the Dutch state. The latter saw imperialism not in those terms, or even in terms of Dutch capitalism alone, but in terms of American, English, Japanese, etc., capitalism--in terms of the capitalist system as a whole. ${ }^{23} \mathrm{~A}$ couple of issues later, there appeared an examination of the various stages of Dutch imperialism, from the first stage of trade monopoly to the sixth (and present) stage of private investment. ${ }^{24}$

What was distinctive in these and other articles was not the general direction of the analysis but the attempt made by Daulat $R a^{\prime}$ jat to achieve system and coherence in developing the analysis. Hatta, for example, after his return from the Netherlands took up the imperialism theme in characteristic manner. Who but Hatta would include, in a lecture on the current world crisis delivered to PNI Baru branches in Cimahi and Bandung, an account of the emergence of capitalism beginning with the Middle Ages and proceeding through the development of a market economy to the Industrial Revolution, referring on the way to under-consumptionist theory, the trade cycle, the technological revolution, the problem of underemployment, and the effect on the working class of social welfare handouts, with accompanying excursions into the history of ideas: Rousseau and the French Revolution, individualism, laissez-faire and the capitalist spirit, Marx, the class struggle, and the materialist conception of history! The climax was a succinct account of the connection between capitalism and imperialism. ${ }^{25}$ It was a typically school-masterly performance, expounding in a few columns a whole political and economic outlook.

A later article, possibly by Sjahrir, extended this theme, ${ }^{26}$ recognizing a family resemblance between the root causes of imperialism and of fascism. The latter,

21. $D R$, No. 14, January 30, 1932.

22. See, for example, Sj-h, "Perdjoeangan Kita dalam Pengertian Perdjoeangan Sosialistis Oemoem" [Our Struggle Seen in the Context of the General Socialist Struggle], $D R$, No. 55, March 20, 1933.

23. "Imperialisme" [Imperialism], DR, No. 23, April 30, 1932.

24. "Imperialisme di Indonesia" [Imperialism in Indonesia], $D R$, No. 25, May 20, 1932 .

25. The address, entitled "Krisis Doenia dan Nasib Ra'jat Indonesia" [World Crisis and the Fate of the Indonesian People], was delivered on September 9, 1932 and was published in two parts in $D R$, Nos. 37 and 38 .

26. S, "Fascisme" [Fascism], DR, No. 44, November 30, 1932. 
like the former, was a reflection of a sick capitalist system, of capitalism in crisis, of capitalism standing on the edge of its grave.

From time to time, the paper gave some attention to the implications of this general analysis of capitalism, imperialism, and fascism for judging the character and the appropriate role of a colonial nationalist movement. The paper, or its contributors, showed some ambiguity or uncertainty regarding the applicability of the notion of class structure to Indonesian circumstances. In early 1932, it was argued that political movements in Asia were based on nationality, rather than on class, and they tended to be led by the more well-to-do sections of society rather than by the poor. It was the paper's plea that the more numerous class must take over the freedom movement. ${ }^{27}$ On other occasions the analysis was more rigorously Marxist in character. Because of the absence of a developed native capitalist class in the colonial situation, the nationalist struggle could not be a bourgeois revolution like the French Revolution, with its ideas of democracy and its destruction of feudalism. In Asia, in the absence of a strong capitalist class, if democracy and the destruction of feudalism were to be attained, this would have to be the task of the State after independence had been achieved. ${ }^{28}$ The journal often distinguished between the political revolution and the social revolution that would have to follow. ${ }^{29}$ But the social revolution was seen as a distant goal. The New PNI was emphatic that it did not intend to launch a revolution in the sense of trying to overthrow the State and to change society by violent means. ${ }^{30}$ Elsewhere, it was pointed out that, for the time being, the embryonic capitalist class of colonial societies could perform a revolutionary role, as it too wanted independence in order to obtain power over the economy. Once that goal was achieved, however, it would lose its revolutionary fervor. ${ }^{31}$

Analyses of this kind were the stock-in-trade of the journal. The self-consciously didactic character of the writing was not confined to Hatta's contributions. In their belief that theoretical understanding was necessary for correct action, the leaders of the New PNI saw themselves as engaged in a task of raising the political consciousness of members and educating them to understand their situation. ${ }^{32}$ The

27. "Krisis Doenia dan Pergerakan Doenia" [The World Crisis and the World Movement ], $D R$, No. 13, January 20, 1932.

28. "Nationalisme" [Nationalism], $D R$, No. 27, June 10, 1932. See also Hatta, "Soal Ekonomi dalam Persatoean Indonesia" [The Economic Question in Indonesian Unity], $D R$, No. 45, December 10, 1932, in which Hatta drew attention not only to linguistic and ethnic divisions within Indonesia, but also to class differences. He noted the fact that in the present situation the large capitalist class was Dutch and the middle class Chinese and Arab, and he was concerned lest, after independence, a native capitalist class might arise.

29. "Perbedaan antara Revoloesi-politik dan Revoloesi-sosial" [The Difference between Political and Social Revolution], DR, No. 106, August 30, 1934.

30. Unsigned article on communism, $D R$, No. 42, November 10, 1932. This article was intended to draw a sharp distinction between a socialist approach to Indonesia's problems and a communist approach.

\section{A, "Revoloesioner" [Revolutionary].}

32. For articles which express these views, see, for example, Dar-Tyb, "Kera'jatan dan Pimpinan dalam 'Pergerakan Kemerdekaan Indonesia'" [Democracy and Leadership in Indonesia's Freedom Movement], DR, No. 4, October 20, 1931; [Sjahrir?], "Barisan Persatoean Baroe"; A, "Pemimpin dan Ra'jat" [Leaders and People], DR, No. 49, January 20, 1933; (Multatuli), "Pendidikan Kita: Bagaimana 
didactic flavor, however, did become particularly noticeable after Hatta's return in September 1932. Almost immediately he contributed to Daulat Ra'jat a leading article entitled "Education" [Pendidikan], which emphasized the educative role of the party. ${ }^{33}$ It referred to the sneers of those of little understanding to the effect that the organization was engaged in schooling, stating, "Indeed we want first to 'go to school' so as to develop insight and understanding, to go to school to strengthen confidence and morale." Thereafter the paper systematically explored and explained the character of the struggle and the situation of world crisis within which it was set, as though by sheer force of character and clarity of instruction Hatta was attempting to forge the New PNI as an appropriate instrument to lead nationalist resistance. In his article on "The World Crisis and the Fate of the Indonesian People," to which reference has already been made, ${ }^{34}$ he spoke of his eleven years' absence in the Netherlands, years which he saw as broadening his own understanding and enabling him to contribute more to the movement. He had no wish, he said, to be a leader who was idolized, but preferred to see himself as one amongst others working together to improve the lot of the people. The fate of Indonesia was in the hands not of leaders but of the common people and the special purpose of the New PNI was to see that from the common people a leader would emerge. These noble sentiments nevertheless contained slightly patronizing overtones. Hatta was confident that he and his colleagues were the appropriate teachers of the "people."

Yet, apart from that sense of a clearer directing intellect at work, and apart from Daulat Ra'jat's sense of the coherence of its views, not much distinguished the rhetoric of the New PNI from that of the old. Even in their discussions of class and of class roles in colonial society the two parties displayed a broad similarity of ideas. This point should be emphasized since it may be a little unexpected. The Marxist style of the analysis given by Hatta and others of the class situation in Indonesia might seem markedly different from Sukarno's concept of the Marhaen rather than a proletariat, and from Sukarno's desire to speak in terms of the unity of all Indonesians against the Dutch rather than in terms of class alignment and class conflict. ${ }^{35}$ But Daulat Raj'at, too, accepted the concept of Marhaenism and frequently used the term, while Sukarno, for his part, though he did not as a rule focus on such questions, could write of a possible conflict after independence between the Marhaen and an emergent Indonesian capitalist class in terms very similar to those of Hatta. ${ }^{36}$ The difference was not in the ideas but in the frequency and the intensity with which the New PNI expressed them.

Against the background of its general analyses of capitalism and imperialism, questions to which Daulat Ra'jat gave specific attention included those of organiza-

Mestinja" [Our Education: How it must be], $D R$, No. 57, April 10, 1933; and (idem), "Djalan Kita: Bagaimana Mestinja" [Our Path: How it must be], $D R$, No. 60, May 10,1933 .

33. $D R$, No. 37, September 20, 1932.

34. See above, n. 25 .

35. This point is made by Ingleson, Road to Exile, pp. 166-67.

36. See, for example, Sukarno, "Mentjapai Indonesia Merdeka," in which he pointed out that political democracy was not enough. He spoke of the "golden bridge" leading to a just society. After the bridge had been crossed, it was important to see that power lay in the hands of the people who could ensure that colonial capitalism was not replaced by Indonesian capitalism. This point is essentially the same as that made by Hatta in his article "Soal Ekonomi dalam Persatoean Indonesia." See above, n. 28 . 
tion, strategy, and tactics. Independence was not to be achieved merely by agitation, said Hatta. It was necessary to be orderly, to move from agitation to organization. ${ }^{37}$ To Sjahrir, organization was one of the principal distinguishing features of a modern radical party. The mere fact of a modern party structure was a feature which marked the nationalist movement off from earlier movements of resistance against the Dutch. ${ }^{38}$ Agitation and propaganda could be effective only if used in an orderly way by men who were determined to work systematically, according to rules and on the basis of calculation.

It is on questions of party organization and strategy that the basic differences between the New PNI and the old PNI would be expected to appear most clearly, if the received view is correct--that from the very formation of the New PNI its leaders were concerned with the creation of a cadre and not a mass party.

Certainly Daulat $R a^{\prime} j a t$ did address these questions: should the PNI be a mass party or a more limited party? What was the proper role for intellectuals to play in it? What should be the nature of party structure? On many occasions questions of strategy and tactics were discussed directly. ${ }^{39}$ But, at least until August 1933, most of these discussions were at a very general level and the themes of these essays were, once again, not so very different from those of the old PNI. Democracy and popular control of the party were emphasized rather than leadership and the training of leaders. Like the old PNI, the new party aimed, so it said, to be a mass party. Though conscious of its educative function, the party at first gave no suggestion of being an intellectual elite preparing the way for a future revolution. That may have been what it was in fact, but it was not how its leaders perceived it or presented it to its members. In Daulat $R a^{\prime} j a t$, No. 4, an article entitled "Democracy and Leadership in Indonesia's Freedom Movement" called for a mass organization. Despite its critical references to Sukarno's rhetoric and to the old PNI's

37. Hatta, "Pendidikan," DR, No. 37, September 20, 1932.

38. Sjahrir, "Organisasi" [Organization], DR, No. 40, October 20, 1932.

39. Articles on the "Principles, Strategy and Tactics of Our Struggle," $D R$, No. 3 , October 10, 1931; "The Opening of the Road of Our Struggle," $D R$, No. 4, October 20, 1931; article by Hatta on the Governor-General's speech to the Volksraad, but commenting also on governments and representative assemblies, $D R$, No. 5 , October 30,1931 ; a discussion running over four issues on the understanding of unity in the strategy and tactics of struggle, $D R$, Nos. $14,15,16$, and 17, January 30 , February 10, February 20, and February 29, 1932; article on the constitution of the New PNI, DR, No. 35, August 30, 1932; Sjahrir, "Organisasi"; ('Hidoep' [pseud.]), "Partai, Organisasi dan Disciplin Massa" [Party, Organization and Mass Discipline], $D R$, No. 43, November 20, 1932; article by Hatta on noncooperation, $D R$, No. 47 , December 30,1932 ; article on mass action, $D R$, No. 48, January 10, 1933; ('Hidoep'), "ABC-Organisasi" [The ABC of Organization], DR, Nos. 53, 55, and 56, February 28, March 20, and March 30, 1933; "Intellectuals and the Movement of the Common People," $D R$, No. 63, June 10, 1933; Hatta, "Kedaulatan Ra'jat Boekan Anarchie" [People's Sovereignty, not Anarchy], DR, No. 65, June 30, 1933; Maskun, "Arah Kemoeka"; "Responsibility in the Movement," DR, No. 78, November 10, 1933; Maskun, "Organization and Discipline," and $\mathrm{Sj}-\mathrm{h}$, "Strategy and Tactics of Struggle," $D R$, No. 80, November 30, 1933; H. H. Koesoemo, "Azas Kedaulatan Ra'jat dengan Perdjoeangan" [The Principle of Popular Sovereignty in the Struggle], $D R$, No. 101, July 10, 1934; Sjamsir, "PNI boekan tergantoeng atas pemimpinpemimpin, tetapi tergantoeng atas ra'jat djelata" [The PNI does not depend on its leaders but on the common people], DR, No. 103, July 30, 1934. 
reliance on agitation, it envisaged a mass party, with leadership responsible to the masses and not the reverse. 40

This was a recurring theme. It was the old PNI, said Hatta, which had rejected the principle of popular sovereignty, the principle which was the lifeblood of the New PNI ; and now Partindo was following the same course. ${ }^{41}$ And insofar as reference was made to the need to educate, it was the mass membership to whom it was directed. In his crucial article on the educative role of the New PNI, ${ }^{42} \mathrm{Hatta}$ 's emphasis was placed not on the creation of a leadership but on the education of the whole people. "By the road of education of the common people the conviction will come that not only must a leader know his responsibility but the whole people also." The article made no reference to a preliminary stage of training the teachers of the masses or to the creation of cadres. Similarly, Sjahrir, when writing specifically on organization, ${ }^{43}$ said nothing about alternative forms of organization or about the necessity for cadre training. The nearest suggestion of such a notion was an earlier assertion that, if the party was in the hands of the people, "although the leadership may fall . . . behind it there will stand a leadership front [Barisan Pemimpin] which can replace it, "44 but that was rather different from a specific idea of cadre training. It had echoes of the view that a mass party was vulnerable since it could be immobilized by a few arrests; but the remedy for the vulnerability was again the training of the whole movement and not of a select band of leaders.

In his alternative statement of the received view, Ingleson argues that, in Sjahrir's definition, a mass party was one which spoke in the language of the masses rather than one which had a mass membership, ${ }^{45}$ and indeed Daulat Ra'jat, on occasion, offered just such a definition. An article of November 1932 defined a mass party as one which cared for the needs of the common people, the needs of the masses, ${ }^{46}$ and an anonymous article a few weeks later stated that a mass party only needed to act completely in the interests of the masses and to speak their language and did not need millions of Marhaen as members. The party's function was as a bridge between the leadership and the masses. ${ }^{47}$ But the remarks in these articles do not seem to be in line with the repeated and continuing emphasis in the pages of Daulat $R a^{\prime} j a t$ on educating a mass membership. And, indeed, even these two articles continued in somewhat different vein. For a mass party to have members who were aware, said the November article, the people as a whole must be trained in correct political theory, and must understand the situation in which they were placed. Only then would they fight heroically and not half-heartedly. The January article, too, said that, in a people's struggle based on the principle of democracy, the leaders must be "born of the people themselves" 48 and feel with the people. It was a constant theme of Hatta that "the fate of the Indonesian people is held in

40. Dar-Tyb, "Kera'jatan dan Pimpinan dalam 'Pergerakan Kemerdekaan Indonesia.'"

41. Hatta, "Pendirian Kita."

42. "Pendidikan."

43. Sjahrir, "Organisasi."

44. Dar-Tyb, "Kera'jatan dan Pimpinan."

45. Ingleson, Road to Exile, p. 150.

46. ('Hidoep'), "Partai, Organisasi dan Disciplin Massa."

47. "Sekedar Tentang Massa-Actie" [Concerning Mass Action], DR, No. 48, January $10,1933$.

48. Article on mass action in $D R$, No. 48, January $10,1933$. 
the hands of the people themselves." 49 "Workers and peasants don't know the theory of capitalism," he said, "but they feel its weight on their skins day by day"; ${ }^{50}$ and later, "I hold the conviction that it is not the leader, however clever and able, but the people themselves who can improve their lot." 51

Early in 1933, three issues of Daulat Ra'jat were devoted to the practical details of party organization. ${ }^{52}$ As was explained in the opening paragraph of the series, the articles were intended to be written not at an academic level of abstract theory but in a manner more easily understood by the general body of party members from whom the future leadership of the party would be drawn. Most of these, it was said, had had no more than a primary school education. This intention was followed faithfully. The articles, complete with organization charts, were devoted entirely to nuts-and-bolts matters: committee structure and membership, the duties of office-bearers, the recruitment of members, methods of budgeting, the formation of branches, the nature of party discipline, and the structure of a possible federal organization of separate parties. Though reference was made to stages of recruitment, from candidate membership to full membership, to the need for the central organization to exercise some control over the policies of branches and subbranches, ensuring that their actions were not in conflict with each other or with the basic theories of the party, and to the need for party discipline, the picture that emerged was of a broadly based, rather than an elite party.

In arguing on these lines, it is not suggested that there were no substantial differences in practice between the way the New PNI went about its business and the approach of Partindo. Sukarno, after his decision to join Partindo in July 1932, was not as influential in that party as he had been in the old PNI, ${ }^{53}$ but it remained his goal to create, as quickly as possible, a party with a huge membership, and Partindo had many more members than the PNI Baru. Sukarno believed that, if Partindo had millions of members, the government's power to crush the party would be reduced. In spite of its professed goal of becoming a mass party, the New PNI was more concerned with the efficiency of its organization and with central control over branches. This was a difference in temper and practice, however, rather than a difference in professed view about the importance of mass preparation and mass action.

Given the concept of a mass party, the role of intellectuals was a continuing worry to Sjahrir, and this was a question to which Daulat Ra'jat continually returned. ${ }^{54}$ There was no bold development of the view that intellectuals should be the leaders and should train the masses. The approach of Daulat Ra'jat was more apologetic--and perhaps more Marxist. The leading role of some intellectuals had to be justified and the justification lay in their responsiveness to the wishes of the masses. ${ }^{55}$ When it came to the preparation of a draft program for the party, the emphasis was on the autonomy of each level of the national organization rather than

49. Hatta, "Pendidikan."

50. Hatta, "Kedaulatan Ra'jat Boekan Anarchie."

51. Hatta, "Krisis Doenia dan Pergerakan Doenia."

52. ('Hidoep'), "ABC-Organisasi." See above, n. 39.

53. Ingleson, Road to Exile, pp. 187-90.

54. See, for example, the article by Sjahrir on the intelligentsia in the world of Indonesian politics, $D R$, No. 6 , November 10,1931 .

55. Pseudonymous article in $D R$, No. 10, December 20, 1931. 
on principles of democratic centralism which might seem more approp riate to a cadre party. ${ }^{56}$

The ideas of the New PNI then, as opposed to its practice--its careful selection of members, the courses it provided for those selected, and its attempts to train members for political action--were less distinctive than the received view would have it, at least for the first two years of its existence. There was, however, a change in the journal's approach from about August 1933. In the changed circumstances following repressive government action against the nationalist movement, the arrest and temporary detention of three leaders of the Surabaya branch of the party in January 1933 and the arrest of Sukarno in August, it was apparent that little time was left for nationalist organizations to operate freely. From then on, a sense of mounting crisis and a concern to prepare for the anticipated time of black reaction ${ }^{57}$ brought Daulat $R a^{\prime}$ jat to the view that the New PNI must become a cadre party. In June $1933 \mathrm{Hatta}$ wrote of the need to limit membership. ${ }^{58}$ Although this might appear contrary to the principles of democracy, it must be recognized that democracy required organization and discipline, and anarchy had to be avoided. The tactic must therefore be to restrict membership, to "sift and educate" (menyaring dan mendidik). The very terms in which this argument was put forward indicated that there had been a change in basic thinking, a modification of the notion of popular control of the movement as it had been viewed earlier. In September 1933, Maskun wrote of the need for politically conscious leaders, and he specifically used the term "cadres." Leaders, he argued, should be seen as spokesmen for the masses. Mass membership was less important than organization, which could, for the time being, stand in for the people. "Indonesian freedom will not be obtained by one man or four thousand but by organizations representing millions of people." 59 He was contemptuous of mass demonstrations. These had a function in letting off steam and in making visible from afar the spirit of the people. But the real strength of the party lay in its organization.

As Hatta remarked shortly afterwards, the "politics of the podium" were no longer possible, but a movement properly based on the understanding of the masses would be able to survive. ${ }^{60}$ We can no longer depend on one leader only, he said. "The Indonesian people must themselves become heroes." 61 The last issues of the paper repeated these themes, though with some differences of emphasis as different authors responded to the crisis. Though the New PNI had been based on the sovereignty of the people, it was now necessary, said one contributor, to emphasize discipline. Centralized discipline was not inconsistent with the principle of popular sovereignty. Freedom was to be for the people in general, not for individuals, and while the movement was fighting against the individualism of capitalism it must limit the freedom of individuals within the organization. ${ }^{62}$ Another contributor, however, argued that the party depended not on its leaders but on the common people and

56. $D R$, No. 11, December 30, 1931. Also see above, n. 16.

57. Leading article in $D R$, No. 69, August 10, 1933.

58. Hatta, "Kedaulatan Ra'jat Boekan Anarchie."

59. Maskun, "Arah Kemoeka."

60. Hatta, "Perpoetaran Soal Keliling 'Persatoean"" [Twisting the Unity Question], $D R$, No. 80, November 30, 1933.

61. Hatta, "Sikap Pemimpin" [The Posture of Leadership], DR, No. 81, December $10,1933$.

62. H. H. Koesoemo, "Azas Kedaulatan Ra'jat dengan Perdjoeangan." 
stressed the importance of the autonomy of local branches, which could work within the general guidelines already laid down by the party. ${ }^{63}$ Four issues later the paper folded.

It would seem from this survey of the contents of Daulat Ra'jat over a threeyear period that, in spite of the New PNI's belief that it represented a very different approach to the nationalist struggle from that of the old PNI and Partindo, the differences were not ideological in character, nor did they at first represent even a markedly different approach to questions of strategy and tactics. One can detect a new didactic temper from September 1932 when Hatta returned. From then on, a more systematic attempt is made to survey various aspects of the world crisis and of the Indonesian nationalist movement's place within it. But nationality and democracy and the idea of a mass movement towards independence remained as central to the rhetoric of the party as they had been to the rhetoric of its predecessors. On the question of the unity of the nationalist movement there was, certainly, a genuine difference. Whereas unity had been absolutely central in the propaganda of the old PNI under Sukarno's leadership, the New PNI put more stress on discipline and what it called political consciousness. Unity was possible and important only where there was agreement on fundamentals. But it was not until late in the period that this view found specific expression in the argument that the membership of the party should be deliberately limited. "Sift and educate," said Hatta--but he said this only in mid-1933. It was only with the imposition by the Indies Government of new policies of repression that the New PNI moved to the idea of a party whose limited and politically conscious membership must be able to survive arrests--to the idea, in short, of a cadre party.

If that reading is correct, the split of 1932 cannot have been the product of ideological differences or even of self-conscious tactical differences between Sukarno and Sartono on the one hand and Hatta and Sjahrir on the other. The differences were differences of temper rather than of ideology, which made the New PNI in a sense a more intellectual organization in fact than was the old PNI, more Western, more in tune with the temper of European social democracy of the thirties. There was a strong desire for intellectual self-improvement that fits in with Ingleson's conclusion that the leadership of the party, apart from Hatta and Sjahrir, was composed of persons drawn from lower social levels than were to be found in Partindo's leadership, people who were educated only to secondary school level, "lesser government officials, clerks or teachers." 64 In due course there did come a more coherent concern with the problems of organization and strategy. But the perception of a deliberately different tactic came after the split in the secular nationalist movement, not before it.

This is perhaps a small point of revision to the received view of the split. Does it matter? In some degree it does. It has relevance, first of all, for one's identification of different traditions within the secular nationalist movement. The differences, it seems, are far from clearcut, and they are not easy to identify in the thirties in terms of theory or ideology. They were important nonetheless. One cannot brush aside Sukarno's continuing suspicion of the leaders of the New PNI, his concern over the years to show that his view of history was as valid as theirs, and his determination to go on fighting his rivals long after they had ceased to be

63. Sjamsir, "PNI boekan tergantoeng atas pemimpin-pemimpin, tetapi tergantoeng atas ra'jat djelata."

64. Ingleson, Road to Exile, p. 193. 
a serious political challenge to him. ${ }^{65}$ He was always sensitive to the fact that he had not studied in Europe, and he always felt vulnerable in the face of their criticisms of him. If there was a distinguishing mark of the PNI Baru as it revealed itself in its own journal, it was its confidence in its own view of the world, its emphasis on the importance of general theory and on the linking of organization and strategy to that theory, and its sense of the coherence and unity of theory. The theory in question derived from the socialist tradition which Hatta and Sjahrir had absorbed in their years in the Netherlands. As expressed in the pages of Daulat Ra'jat it was not especially elaborate, or coherent, or even--as has been argued here--particularly distinctive. But the leaders of the PNI Baru nevertheless felt it to be coherent and distinctive, and that was the important thing. They saw themselves as having a rational view of the world in which capitalism, imperialism, the rise of fascism--indeed the whole course of history--were all of a piece. Much space was spent in the journal in examining developments elsewhere in the world. Specific attention was given to Mussolini's fascism and to developments in Germany . Fascism was seen not as a local Italian or German product but, more generally, as a product of capitalism in crisis. There were discussions of the special character of fascism in Japan and of the nature of Japanese imperialism in Manchuria. ${ }^{66}$ Apart from specific articles on these issues, a column surveying events in the outside world became a regular feature of the paper. Though nationalist in temper, Daulat Ra'jat was aware of the authoritarian implications of a good deal of nationalist thought, and it was careful to draw a distinction between the nationalism of National Socialism in Germany and that of Asian countries, where freedom from foreign overlordship was a necessary prerequisite for social change and where the establishment of an independent state was therefore to be understood as historical progress. ${ }^{67}$ In developing its world view, the party was always critical of the less disciplined, more expressive language of the old PNI. Its leaders were confident that they were in tune with sophisticated radical circles in Europe, and they felt themselves to share with those circles a common perception of events as they were unfolding in the early thirties.

This sense of a distinctive PNI Baru approach, then, was a consistent feature of Daulat Ra'jat, and just as it helped to define some of the followers of Hatta in the early thirties so it was an element in defining the circle that formed about Sjahrir in the mid-forties, when student groups began to form towards the close of the Japanese occupation, when they played a part in the domestic politics of the independence struggle, and when the Indonesian Socialist Party stream gradually became first an influential, and then an impotent but critical element in the independent Republic. How far a clear theoretical position in fact existed at that later time, and how far the PSI was really defined by that position, is a matter for further study.

There are also implications in this for subsequent historiography. Since 1952 (the date of Kahin's Nationalism and Revolution in Indonesia) there has been a change in attitude with regard to the PSI stream in Indonesian politics. Twentyfive years ago Western students of Indonesia tended to focus on the Western-

65. For a discussion of this point, see Legge, Sukarno, pp. 126-28, 235-37, 308-9.

66. See, for example, articles on "Imperialisme Djepang di Mansjoeria" [Japanese Imperialism in Manchuria], and "Fascisme" in $D R$, No. 44, November 30,1932 . See also Suparman, "Nasional Socialisme di Tanah Djerman" [National Socialism in Germany], $D R$, No. 73, September 20, 1933.

67. See, for example, pseudonymous article on "Nationalism" (see above, n. 28), and $\mathrm{S}$, "Fascisme" (see above n. 66). 
educated socialist element within the elite. Men who were "Western" in their outlook, who had close links with Western observers, and who shared values and indeed a whole outlook with them, were seen as the central stream in the politics of revolution and independence. In 1950 this group was seen as holding the key to the future--a peaceful, progressive, democratic future. These hopes were not fulfilled, and Western scholars, in commenting on the politics of the fifties and focusing on intraelite rivalries, frequently could not conceal their disappointment at the failure of liberal democracy and later their concern at the authoritarian character of Sukarno's Guided Democracy. By the late fifties most remaining leaders of the PSI were acting merely as impotent critics of government, and that fact led later students of the thirties, forties, and early fifties to underestimate the role Sjahrir and his followers had played even during the revolution and the early years of the Republic. These later Western observers were, at the same time, less concerned with political pressure groups and rivalries within the elite, and more with the society in which the pressure groups operated. They noticed the strength of traditional social patterns, subcultures, aliran--distinct streams within Indonesian society which were resistant to change and which were important in shaping the distinctive behavior of different socio-religious segments of Javanese, Minangkabau, Acehnese, and other ethnic groups. An awareness of these patterns affected the way in which observers of the national scene came to look at party alignments, presidential initiatives, and the political role of the army. At the end of the revolution, the orthodoxy amongst academic Indonesia watchers assumed the desirability of a democratic solution for Indonesia. Later writers, by stressing the cultural components of political action, tended to legitimize what had actually happened--to find interpretative schemes which, by implication, justified the Sukarno regime.

Amongst other things the shift in focus had its effect on the way in which the split in the secular nationalist movement of 1932 was interpreted. At least in part, this split appeared as a difference between the Sumatran leaders of the nationalist movement as against the Javanese, rather than as a matter of personal rivalry or of ideological difference or of rational disagreements about tactics. Such an interpretation would have to assign considerable weight to the roles of Hatta and Sjahrir, for in terms of membership figures the PNI Baru was in fact strongest in Java. And it would also need to underplay quite genuine differences of outlook. Once again, for the Pendidikan there was a consciousness of its ideological coherence. If the pages of Daulat Ra'jat suggest that the party's ideas were not, on the whole, so very distinct from those of their Partindo rivals, they do nevertheless reflect the party's confidence in a considered world-view within which its political strategy should be set. 